\title{
Relative importance of vascular plants and algal production in the food web of a Spartina-invaded salt marsh in the Yangtze River estuary
}

\author{
X. Shang ${ }^{1,2, *}$, G. S. Zhang ${ }^{1}$, J. Zhang ${ }^{1}$ \\ ${ }^{1}$ State Key Laboratory of Estuarine and Coastal Research, East China Normal University, 3663 Zhongshan Road North, \\ Shanghai 200062, PR China \\ ${ }^{2}$ School of Environment and Public Health, Wenzhou Medical College, Wenzhou 325035, PR China
}

\begin{abstract}
The trophic importance of microphytobenthos (MPB), phytoplankton, $\mathrm{C}_{3}$ vascular plants and invasive Spartina alterniflora in benthic and pelagic food webs was studied in Jiuduansha, a newly formed salt marsh in the Yangtze River estuary, using natural stable carbon and nitrogen isotopic analyses and IsoSource evaluation. MPB was found to be the major food source of meiofauna and important in the diets of macrofaunal consumers. Carbon derived from $\mathrm{C}_{3}$ vascular plants significantly contributed to the nutrition of all planktonic copepods and supported planktivorous nekton, but played a minor role in the benthic food web. Although phytoplankton could be utilized by all the consumers, low production in this highly turbid estuary might restrict its relative importance. High trophic-level consumers could get carbon from ${ }^{13} \mathrm{C}$-enriched MPB and ${ }^{13} \mathrm{C}$-depleted $\mathrm{C}_{3}$ plants via zoobenthos and zooplankton, respectively. Neither benthic nor pelagic animals fed exclusively on $S$. alterniflora except for a gastropod species in the present study, indicating a minor contribution of this invasive $\mathrm{C}_{4}$ plant to the food web of the Jiuduansha salt marsh. In light of the degradation of salt marshes in the Yangtze River estuary, the rapid expansion of this invasive $\mathrm{C}_{4}$ plant may alter the nutrient foundation of resident and migratory consumers and thus significantly impact the ecosystem there.
\end{abstract}

KEY WORDS: Salt marsh - Food web - Microphytobenthos - Spartina alterniflora - Invasion · Trophic shift

\section{INTRODUCTION}

Salt marshes are among the most productive ecosystems in the world (Odum 1961, Pomeroy \& Wiegert 1981) and also known to function as nursery areas for many fish and invertebrate species (Boesch \& Turner 1984, Kneib 1997). As salt marshes are thought to be important in combating eutrophication and rapid decline of fisheries in coastal waters (Teal \& Howes 2000), 'determining the importance of marsh grass production for secondary production in estuaries is critical because of the intense development pressures on coastal ecosystems ...' (Peterson \& Fry 1987).

Since pioneer investigators have pointed to the importance of detritus-based food webs both within the marsh and in the adjacent estuarine and coastal waters (Teal 1962, Odum \& de la Cruz 1967), the actual nutritional value of vascular plant detritus has been questioned (Boesch \& Turner 1984). Although some investigations show direct use of vascular plant matter by gastropods (Silliman \& Zieman 2001), decapods (McClintock et al. 1991) and fish (Lewis \& Peters 1984), these results derived from traditional methods used in food web studies, such as gut content studies, seem to be insufficient to describe trophic interactions. For example, not all ingested material can be assimilated (Michener \& Schell 1994); the refractory nature of vascular plant detritus may lead to overestimation in gut content analysis, while more digestible organisms, such as nematodes, can be assimilated very quickly 
and are seldom found in predators' stomachs (Gee 1989). Stable isotope analysis provides a powerful tool to measure assimilated, and therefore nutritionally important, materials among diets; hence the relative contribution of different food sources can be identified (Peterson et al. 1985, Vander Zanden \& Rasmussen 2001). In general, stable carbon isotope ratios $\left(\delta^{13} \mathrm{C}\right)$ exhibit little or no enrichment (within 1\%o) relative to diet and are thus useful for determining the food sources of consumers (DeNiro \& Epstein 1978, Peterson \& Fry 1987). Stable nitrogen isotope ratios become enriched by 3 to $4 \%$ between prey and predator tissues, thereby providing a measure of consumer trophic position (DeNiro \& Epstein 1981, Peterson \& Fry 1987).

According to distinct carbon isotope signatures between $\mathrm{C}_{3}$ and $\mathrm{C}_{4}$ salt marsh vascular plants (Smith \& Epstein 1971), and consistent within-site differences between planktonic and benthic algae (France 1995), stable carbon isotope ratios are widely used to distinguish the relative contribution of salt marsh primary producers. In spite of the visible large amount of biomass represented as vascular plants in salt marshes, carbon isotope signatures of consumers are frequently consistent with an algal-based food web (Sullivan \& Moncreiff 1990, Riera et al. 1999). In particular, microphytobenthos (MPB) has been shown to be a major source of nutrition in salt marsh food webs, for it is more nutritious and can be more readily utilized by consumers than vascular plants (Pomeroy \& Wiegert 1981, Miller et al. 1996). Moreover, MPB has rapid turnover rates and can grow year-round; it represents up to $40 \%$ of terrestrial plant production in salt marshes or even more (Pinckney \& Zingmark 1993). Although recent studies based on in situ isotopic labeling further confirm the central role of MPB in intertidal benthic food webs (Herman et al. 2000, Middleburg et al. 2000), stable isotopic analyses also show that vascular plants may supply a considerable part of the nutrient requirements of many marsh consumers (Currin et al. 1995, Carman \& Fry 2002). However, the longstanding debate about the relative importance of primary producers will go on accompanied with spatial and temporal variations between salt marsh food webs, and more evidence from different regions can enhance knowledge about the function of salt marshes.

The Yangtze River is one of the largest rivers in the world. Jiuduansha, consisting of 3 newly formed islands, formed as a consequence of the sedimentation of silt brought by the Yangtze River. Since its emergence in the 1920s, Jiuduansha has been expanding rapidly. As a part of the Yangtze delta wetlands, one of the world's major wetland ecosystems ( $\mathrm{Lu} \mathrm{1997),} \mathrm{it}$ has been designated as a wetland nature reserve by the Chinese government. While Jiuduansha salt marsh has been considered an important nursery habitat for many fishery nekton species and migratory birds (Chen et al. 2003), the native salt marsh flora is being quickly replaced by introduced Spartina alterniflora, and the ecosystem and coastal fishery are thought to be seriously threatened by invasion of Spartina (Li et al. 2006, Huang \& Zhang 2007). As the food web of Jiuduansha salt marsh has never been investigated intensively, the importance of different primary producers is unknown, especially the contribution of MPB and the invasive Spartina, so that it is difficult to estimate the role of this marsh in the Yangtze River estuary ecosystem and the ecological impact of the rapid expansion of Spartina. We hypothesis that MPB may be an important food source in this estuarine salt marsh, and consumers may prefer native salt marsh flora to invasive Spartina. In the present study, we tested these hypotheses by comparing the carbon and nitrogen stable isotope composition of dominant consumers with that of their potential food sources, in order to evaluate the importance of different primary producers and the impact of Spartina invasion on the food base of native marsh animals.

\section{MATERIALS AND METHODS}

Study area. The present study was conducted at Jiuduansha Wetland Nature Reserve in the Yangtze River estuary (between $121^{\circ} 46^{\prime}$ and $122^{\circ} 15^{\prime} \mathrm{E}, 3^{\circ} 03^{\prime}$ and $31^{\circ} 17^{\prime} \mathrm{N}$ ) (Fig. 1). It covers $520 \mathrm{~km}^{2}$ (above $-6 \mathrm{~m}$ isobath, according to the definition of Wetland International), including $114.6 \mathrm{~km}^{2}$ above $0 \mathrm{~m}$ isobath (Chen et al. 2003), and consists mainly of an upper island, a middle island and a lower island. Tides at Jiuduansha are semidiurnal with the maximum and average tidal amplitude of 4.62 and $2.67 \mathrm{~m}$, respectively. During the high spring tide, most of the upper island and the whole of the middle and lower islands are submerged by tidewater (Chen et al. 2003). There are no regular residents in Jiuduansha, and thus there is little artificial disturbance except for small-scale fishing and reed harvesting in the winter (Ma et al. 2007).

The dominant vascular plants in Jiuduansha islands are the reed Phragmites australis on the high tide zone and part of middle tide zone, bulrush Scirpus mariqueter on the middle tide zone and smooth cordgrass Spartina alterniflora on both the high and middle tide zones. The vegetated areas are surrounded by wide intertidal mud flats (Chen et al. 2003). Since its introduction to the Jiuduansha islands in 1997, the area $S$. alterniflora occupies has an average annual expansion rate of $>60 \%$, and has replaced large areas formerly covered by $P$. australis (Huang \& Zhang 2007). S. alterniflora has also started to invade the upper parts of the S. mariqueter zone (Li et al. 2006). 


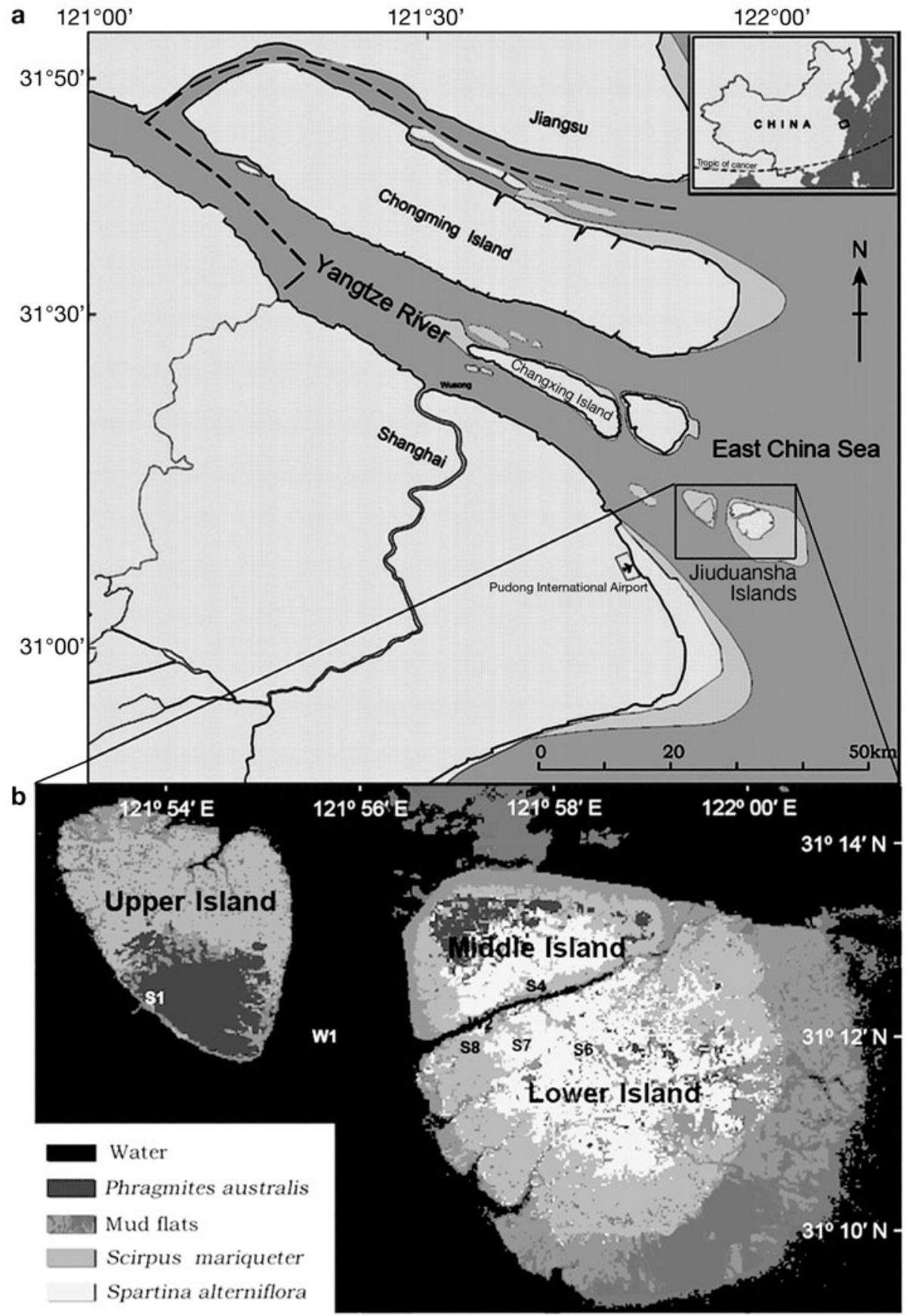

Fig. 1. (a) The Yangtze River Estuary and (b) Jiuduansha islands showing locations of sampling sites

Sample collection and preparation. Two surveys of sampling were performed in summer (June 2006) and winter (December 2006) from 5 sites on land (S1, S4 and S6 to S8) and 2 sites in the water (W1 and W2) (Fig. 1). Depending on the environment surrounding each site, the samples were collected from more than one vegetation type (e.g. in S4 we collected samples from the creek bank and nearby bulrush and cordgrass zones).

The live and dead (in winter) leaves of 3 dominant vascular plants, Scirpus mariqueter, Phragmites aus- tralis and Spartina alterniflora, were collected by hand, and each sample was taken from a different colony of plants.

The MPB here is dominated by Nizschia and Navicula species both in summer and winter (unpubl. obs.). Based on the properties of vertical migration of motile diatoms, they were separated from the mud following Blanchard et al.'s (2004) method. Three $55 \mu \mathrm{m}$ mesh size nylon screens were laid on the sediment surface for a few hours during low tide, and the upper 2 
screens were then removed from the sediment before re-flood. Diatoms were removed from the screens by rinsing with GF/F $(0.45 \mu \mathrm{m})$ filtered in situ water, and the resulting suspension of MPB was filtered onto a precombusted Whatman GF/F glass fiber filter. Examination under a dissecting microscope revealed there were few animals (nematodes) and only small quantities of detritus in screen samples.

Plankton samples were collected by towing plankton nets with mesh size of $37 \mu \mathrm{m}$ for phytoplankton and $160 \mu \mathrm{m}$ for zooplankton in the large tidal creek between the upper and middle islands from a large anchored boat (W1 in Fig. 1) and in 2 small tidal creeks from a small boat. Phytoplankton samples were separated through a series of sieves (160 and $37 \mu \mathrm{m}$ mesh) to eliminate large particles (e.g. zooplankton or debris of vascular plants) and resulted in a mixture consisting mostly of diatoms, along with some detritus derived from unknown organic matter, a few copepod nauplii and sand. The $37 \mu \mathrm{m}$ sieve sample was washed several times with deionized water and concentrated onto a precombusted GF/F filter. Suspended particulate matter (SPM) samples were collected by filtering $300 \mathrm{ml}$ to 21 creek water onto precombusted GF/F filters, according to the turbidity of the water. Four dominant copepods present in zooplankton samples, Pseudodiaptomus poplesia, Sinocalanus sinensis, Limnoithona sinensis and Tortanus vermiculus, were identified under a dissecting microscope and sorted out by pipette. After sorting, all these copepods were held in $\mathrm{GF} / \mathrm{F}$ filtered in situ water for at least $12 \mathrm{~h}$ to allow gut evacuation.

According to their abundance in the sediment, meiofauna were extracted from 100 to $500 \mathrm{ml}$ of surface sediment by sieving in a series of stainless-steel sieves (1 $\mathrm{mm}$ and $50 \mu \mathrm{m}$ ). Nematodes and harpacticoids were sorted manually under a dissecting microscope and then starved $12 \mathrm{~h}$ in filtered in situ water to clean gut contents. After starvation, any debris adhering to meiofauna was carefully removed.

The dominant ocypodid crab in Jiuduansha islands, Ilyoplax deschampsi, was excavated from the sediment with a stainless spatula. Gastropods Assiminea violacea and mudskippers Boleophthalmus pectinirostris were collected by hand. Bivalves Corbicula fluminea were collected by sieving sediment in creek water with a $1 \mathrm{~mm}$ mesh sieve. All these macrofauna were washed carefully with creek water to remove the sediment particles.

Resident nekton species, including the mullet Mugil cephalus, goby Synechogobius ommaturus and shrimp Palaemon sp., were obtained from the fish newly caught by fishermen fishing in the waters surrounding the Jiuduansha islands.

All the samples were stored in a freezer onboard and kept frozen under $-20^{\circ} \mathrm{C}$ until laboratory processing.
In the laboratory, vascular plant samples were rinsed vigorously in tap water and then in deionized water to remove epiphytic material, dried at $60^{\circ} \mathrm{C}$ for $48 \mathrm{~h}$ and crushed with a stainless-steel disintegrator prior to analysis. GF/F filters containing phytoplankton and MPB were dried at $60^{\circ} \mathrm{C}$ for $24 \mathrm{~h}$. Individual planktonic copepods and meiofauna provided insufficient tissue for isotopic analysis, thus 10 to 100 ind. were pooled as one sample. Foot muscle of gastropods and bivalves, dorsal muscle of fish and shrimp, and muscle in the chelae of crab were dissected and the debris of skeleton or exoskeleton were removed carefully with forceps and needles under dissecting microscope. After washing in deionized water they were dried at $60^{\circ} \mathrm{C}$ for at least $24 \mathrm{~h}$. The muscle tissues of all these consumers were ground to powder. All samples were treated in replicate or triplicate if possible. Because acidification may alter $\delta^{15} \mathrm{~N}$ values and result in an increase in the variation among individuals for both $\delta^{13} \mathrm{C}$ and $\delta^{15} \mathrm{~N}$ (Bunn et al. 1995, Bosley \& Wainright 1999), none of the filters or the animal samples was acidified.

Stable isotope analysis. Samples for stable isotope analysis were combusted in a Flash 1112 EA Elemental Analyser, and the resulting gases (i.e. $\mathrm{CO}_{2}$ and $\mathrm{N}_{2}$ ) were cryogenically separated and passed online to an isotope ratio mass spectrometer (Delta plus XP Finnigan) to determine ${ }^{13} \mathrm{C} /{ }^{12} \mathrm{C}$ and ${ }^{15} \mathrm{~N} /{ }^{14} \mathrm{~N}$. The results are expressed as per thousand (\%) differences from the conventional standards, i.e. PDB for carbon and atmospheric $\mathrm{N}_{2}$ for nitrogen:

$$
\delta X=\left[\left(R_{\text {sample }} / R_{\text {standard }}\right)-1\right] \times 10^{3}
$$

where $X={ }^{13} \mathrm{C}$ or ${ }^{15} \mathrm{~N}$, and $R={ }^{13} \mathrm{C} /{ }^{12} \mathrm{C}$ for carbon or ${ }^{15} \mathrm{~N} /{ }^{14} \mathrm{~N}$ for nitrogen. Reproducibility in the analyses was $\pm 0.1 \%$ for $\delta^{13} \mathrm{C}$ and $\pm 0.2 \%$ or $\delta^{15} \mathrm{~N}$.

The relative importance of different food sources in the diets of consumers in Jiuduansha islands was estimated by IsoSource (Phillips \& Gregg 2003, www.epa. gov/wed/pages/models/stableIsotopes/isotopes.htm). Seven groups of dominant organic matter sources which presented dissimilar $\mathrm{C}$ and $\mathrm{N}$ isotope values were entered into IsoSource calculations: live and dead leaves of $\mathrm{C}_{3}$ and $\mathrm{C}_{4}$ vascular plants, phytoplankton, MPB and SPM, resulting in a 7 -source, 2-isotope $(\mathrm{C}, \mathrm{N})$ mixing model. As no dead leaves of vascular plants were sampled in summer, the isotope values of dead leaves of vascular plants in winter were constructed into the summer mixing model. Copepods and meiofauna consumers presented similar $\delta^{13} \mathrm{C}$ and $\delta^{15} \mathrm{~N}$ values, respectively, and were calculated in groups. Macrofauna and nekton consumers were calculated separately, as they occupied different niches or exhibited different feeding behaviour. For herbivorous primary consumers, trophic fractionation of ${ }^{13} \mathrm{C}$ were $0.5 \%$ for consumers analyzed whole and $1.3 \%$ for con- 
sumers analyzed as muscle; trophic fractionation of ${ }^{15} \mathrm{~N}$ were $2.2 \%$ (McCutchan et al. 2003). For nekton species which were assumed to be second-level or even higher trophic consumers, the expected trophic enrichment of ${ }^{13} \mathrm{C}$ and ${ }^{15} \mathrm{~N}$ were $1.8 \%$ o $(0.5+1.3)$ and $5.5 \%$ $(2.2+3.3)$, respectively (according to McCutchan et al. 2003). In IsoSource analyses, the increment was set at $1 \%$, and the tolerance was initially set at $0.1 \%$. If no solution was obtained under this tolerance then it was increased up to a maximum of $1.5 \%$. The contributions of each source were estimated by their minimum and maximum feasibility, as low maxima indicated the source was unimportant and high minima indicated the source might be important (Benstead et al. 2006).

\section{RESULTS}

\section{Stable isotope ratios of primary producers}

The $\delta^{13} \mathrm{C}$ values of primary producers varied from -27 to $-13 \%$, and variation within taxa was small (Table 1). Most standard errors of mean values were less than $0.4 \%$ in summer and $0.5 \%$ in winter; only the variation of phytoplankton and SPM exceeded $0.7 \%$. The carbon isotope ratios of $\mathrm{C}_{3}$ and $\mathrm{C}_{4}$ vascular plants were distinct, and only small seasonal variation had been found, thus it was easy to separate the carbon source derived from $\mathrm{C}_{3}$ and $\mathrm{C}_{4}$ plants. Spartina alterniflora was the most ${ }^{13} \mathrm{C}$-enriched producer both in summer $(-13.2 \pm 0.1 \%$ o $)$ and winter $\left(-13.1 \pm 0.1 \%\right.$, while $\mathrm{C}_{3}$ plants showed the most depleted $\delta^{13} \mathrm{C}$ values $(-27.2 \pm$

Table $1 . \delta^{13} \mathrm{C}$ and $\delta^{15} \mathrm{~N}$ values (mean $\pm \mathrm{SE}$, \%o) for primary producers in the Jiuduansha islands during summer and winter. MPB: microphytobenthos; SPM: suspended particulate matter; $n$ : no. of samples of pooled material analysed; ns: not sampled

\begin{tabular}{|c|c|c|c|c|c|c|}
\hline \multirow{2}{*}{ Producer } & \multicolumn{3}{|c|}{ Summer- } & \multicolumn{3}{|c|}{ Winter } \\
\hline & $\delta^{13} \mathrm{C}$ & $\delta^{15} \mathrm{~N}$ & $\mathrm{n}$ & $\delta^{13} \mathrm{C}$ & $\delta^{15} \mathrm{~N}$ & $\mathrm{n}$ \\
\hline \multicolumn{7}{|l|}{$\mathrm{C}_{3}$ plants } \\
\hline \multicolumn{7}{|l|}{ Scirpus mariqueter } \\
\hline Fresh leaves & $-27.2 \pm 0.2$ & $7.1 \pm 0.2$ & 3 & $-26.5 \pm 0.3$ & $5.3 \pm 0.2$ & 2 \\
\hline Dead leaves & $\mathrm{ns}$ & ns & & $-26.6 \pm 0.2$ & $2.0 \pm 0.4$ & 2 \\
\hline \multicolumn{7}{|l|}{ Phragmites australis } \\
\hline Fresh leaves & $-26.4 \pm 0.2$ & $5.7 \pm 0.3$ & 3 & ns & ns & \\
\hline Dead leaves & ns & ns & & $-26.8 \pm 0.2$ & $3.3 \pm 0.8$ & 2 \\
\hline \multicolumn{7}{|l|}{$\mathrm{C}_{4}$ plants } \\
\hline \multicolumn{7}{|l|}{ Spartina alterniflora } \\
\hline Fresh leaves & $-13.2 \pm 0.1$ & $4.2 \pm 0.3$ & 3 & $-13.1 \pm 0.1$ & $5.0 \pm 0.3$ & 2 \\
\hline Dead leaves & $\mathrm{ns}$ & ns & & $-13.1 \pm 0.2$ & $2.3 \pm 0.4$ & 2 \\
\hline Phytoplankton & $-21.4 \pm 0.6$ & $5.2 \pm 0.2$ & 3 & $-19.8 \pm 0.7$ & $4.8 \pm 0.3$ & 3 \\
\hline \multicolumn{7}{|l|}{ MPB } \\
\hline Bare flat & $-19.8 \pm 0.4$ & $6.9 \pm 0.2$ & 2 & $-17.1 \pm 0.3$ & $6.3 \pm 0.2$ & 2 \\
\hline Creek bank & $-19.3 \pm 0.3$ & $7.5 \pm 0.3$ & 2 & $-16.6 \pm 0.5$ & $6.6 \pm 0.2$ & 2 \\
\hline Upland creek bank & ns & ns & & $-13.7 \pm 0.3$ & $7.3 \pm 0.3$ & 3 \\
\hline SPM & $-23.2 \pm 1.1$ & $1.8 \pm 0.4$ & 4 & $-22.4 \pm 0.8$ & $2.1 \pm 0.5$ & 2 \\
\hline
\end{tabular}

$0.2 \%$ in summer and $-26.5 \pm 0.3 \%$ in winter for Scirpus mariqueter, $-26.4 \pm 0.2 \%$ in summer and $-26.8 \pm 0.2 \%$ in winter for Phragmites australis).

Two categories of algal producer, phytoplankton and $\mathrm{MPB}$, presented relatively wide ranges of $\delta^{13} \mathrm{C}$. MPB showed more enriched values than phytoplankton and exhibited remarkable seasonal and regional shifts (from $-19.8 \pm 0.4 \%$ on the creek banks in summer to $-13.7 \pm 0.3 \%$ on the upland creek bank in winter). In contrast, ${ }^{13} \mathrm{C}$-depleted phytoplankton displayed a slight seasonal difference of $1.6 \%$. The $\delta^{13} \mathrm{C}$ of SPM were more depleted than phytoplankton both in summer and winter, implying $\delta^{13} \mathrm{C}$ depleted organic matter derived from terrestrial $\mathrm{C}_{3}$ plants might constitute a considerable proportion in SPM.

The $\delta^{15} \mathrm{~N}$ of primary producers were most enriched for MPB both in summer $(7.5 \pm 0.3 \%$ ) and winter $(7.3$ to $0.3 \%$ ) among producers and most depleted for SPM in summer $(1.8 \pm 0.4 \%$ o $)$ and dead tissue of Scirpus mariqueter in winter $(2.0 \pm 0.4 \%)$. As the stable nitrogen isotope ratios of autochthonous primary producers (except for the depleted dead tissue of vascular plants) fell in a relatively narrow range $(4.2$ to $7.5 \%$ in summer and 4.8 to $7.3 \%$ in winter), the $\delta^{15} \mathrm{~N}$ values did not discriminate as well as carbon between these primary producers.

\section{Stable isotope ratios of consumers}

The stable carbon isotopic composition of consumers was highly variable (Table 2), ranging from $-24.6 \pm$ $0.5 \%$ for the calanoid Pseudodiaptomus poplesia to $-16.0 \pm 0.1 \%$ for the mullet Mugil cephalus in summer and $-25.9 \pm 0.3 \%$ o for $P$. poplesia to $-13.7 \pm 0.3 \%$ or harpacticoids in winter. Because the $\delta^{13} \mathrm{C}$ values of all the 4 species of planktonic copepods were not higher than $-23 \%$, these ${ }^{13} \mathrm{C}$-depleted pelagic consumers could be distinguished from other consumers easily. Among the other consumer samples, most $(73 \%)$ of them had $\delta^{13} \mathrm{C}$ values falling within a range of -20.4 to $-17.5 \%$ in summer, and the $\delta^{13} \mathrm{C}$ values of over $60 \%$ consumer samples fell within a range of -19.2 to $-15.8 \%$ in winter; thus food sources whose $\delta^{13} \mathrm{C}$ values fell in or near these ranges might contribute substantially to the food web of Jiuduansha salt marsh.

As the most depleted category of consumers, the overall range of $\delta^{13} \mathrm{C}$ values for planktonic copepods fell between $\mathrm{C}_{3}$ vascular plants and phytoplankton. 
Table 2. $\delta^{13} \mathrm{C}$ and $\delta^{15} \mathrm{~N}$ values (mean $\pm \mathrm{SE}$, \%) for consumers in the Jiuduansha islands during summer and winter. n: no. of samples of pooled material analysed; ns: not sampled

\begin{tabular}{|c|c|c|c|c|c|c|}
\hline \multirow{2}{*}{ Consumer } & \multicolumn{3}{|c|}{ Summer } & \multicolumn{3}{|c|}{ - Winter } \\
\hline & $\delta^{13} \mathrm{C}$ & $\delta^{15} \mathrm{~N}$ & $\mathrm{n}$ & $\delta^{13} \mathrm{C}$ & $\delta^{15} \mathrm{~N}$ & $\mathrm{n}$ \\
\hline \multicolumn{7}{|l|}{ Planktonic copepods } \\
\hline $\begin{array}{l}\text { Pseudodiaptomus } \\
\text { poplesia }\end{array}$ & $-24.6 \pm 0.5$ & $9.2 \pm 0.4$ & 3 & $-25.9 \pm 0.3$ & $7.4 \pm 0.4$ & 3 \\
\hline Sinocalanus sinensis & $-23.9 \pm 0.3$ & $8.3 \pm 0.4$ & 3 & $-23.6 \pm 0.4$ & $8.2 \pm 0.2$ & 3 \\
\hline Limnoithona sinensis & $-23.6 \pm 0.3$ & $10.0 \pm 0.3$ & 2 & $-23.5 \pm 0.3$ & $9.0 \pm 0.2$ & 2 \\
\hline Tortanus vermiculus & $-23.1 \pm 0.1$ & $12.1 \pm 0.2$ & 2 & $-22.7 \pm 0.3$ & $12.3 \pm 0.2$ & 2 \\
\hline \multicolumn{7}{|l|}{ Meiofauna } \\
\hline \multicolumn{7}{|l|}{ Nematoda } \\
\hline Bare flat & $-18.5 \pm 0.2$ & $8.2 \pm 0.2$ & 2 & -16.2 & 7.4 & 1 \\
\hline Creek bank & $-18.8 \pm 0.2$ & $8.0 \pm 0.3$ & 2 & $-17.8 \pm 0.4$ & $7.2 \pm 0.4$ & 2 \\
\hline Bulrush zone & $-19.6 \pm 0.3$ & $7.2 \pm 0.4$ & 2 & $-17.6 \pm 0.3$ & $5.9 \pm 0.2$ & 2 \\
\hline Upland creek bank & ns & $\mathrm{ns}$ & & $-14.0 \pm 0.5$ & $7.7 \pm 0.2$ & 3 \\
\hline \multicolumn{7}{|l|}{ Harparcticoida } \\
\hline Bare flat & $-18.2 \pm 0.2$ & $8.6 \pm 0.1$ & 2 & $-15.9 \pm 0.4$ & $7.9 \pm 0.3$ & 2 \\
\hline Creek bank & $-18.9 \pm 0.3$ & $7.9 \pm 0.2$ & 2 & $-17.1 \pm 0.2$ & $7.9 \pm 0.4$ & 2 \\
\hline Bulrush zone & $-20.1 \pm 0.3$ & $6.7 \pm 0.4$ & 2 & $-18.7 \pm 0.3$ & $6.9 \pm 0.4$ & 2 \\
\hline Upland creek bank & ns & ns & & $-13.7 \pm 0.3$ & $8.6 \pm 0.3$ & 3 \\
\hline \multirow{2}{*}{\multicolumn{7}{|c|}{$\begin{array}{l}\text { Macrofauna } \\
\text { Ilyoplax deschampsi }\end{array}$}} \\
\hline & & & & & & \\
\hline Creek bank & $-19.0 \pm 0.2$ & $10.0 \pm 0.3$ & 2 & $-16.2 \pm 0.4$ & $9.8 \pm 0.3$ & 2 \\
\hline Bulrush zone & $-19.5 \pm 0.3$ & $9.0 \pm 0.1$ & 2 & $-16.8 \pm 0.1$ & $8.5 \pm 0.3$ & 2 \\
\hline Cordgrass zone & $-21.5 \pm 0.4$ & $9.1 \pm 0.2$ & 2 & $-18.6 \pm 0.3$ & $8.2 \pm 0.2$ & 3 \\
\hline Corbicula fluminea & $-23.0 \pm 0.2$ & $10.3 \pm 0.2$ & 2 & $-19.7 \pm 0.4$ & $8.7 \pm 0.3$ & 2 \\
\hline \multicolumn{7}{|l|}{ Assiminea violacea } \\
\hline Creek bank & $-18.6 \pm 0.2$ & $7.4 \pm 0.3$ & 2 & $-18.1 \pm 0.3$ & $8.2 \pm 0.3$ & 2 \\
\hline Bulrush zone & $-18.9 \pm 0.3$ & $6.9 \pm 0.5$ & 2 & $-18.8 \pm 0.4$ & $8.1 \pm 0.2$ & 2 \\
\hline Cordgrass zone & $-16.2 \pm 0.3$ & $6.0 \pm 0.2$ & 2 & $-20.6 \pm 0.3$ & $7.4 \pm 0.3$ & 3 \\
\hline $\begin{array}{l}\text { Boleophthalmus } \\
\text { pectinirostris }\end{array}$ & $-17.7 \pm 0.2$ & $10.7 \pm 0.1$ & 2 & ns & $\mathrm{ns}$ & \\
\hline \multicolumn{7}{|l|}{ Nekton } \\
\hline Palaemon sp. & -17.0 & 12.6 & 1 & ns & ns & \\
\hline Mugil cephalus & $-16.0 \pm 0.1$ & $12.4 \pm 0.3$ & 2 & $-15.2 \pm 0.2$ & $11.4 \pm 0.2$ & 2 \\
\hline $\begin{array}{l}\text { Synechogobius } \\
\text { ommaturus }\end{array}$ & $-19.8 \pm 0.3$ & $14.2 \pm 0.2$ & 2 & $-22.0 \pm 0.3$ & $13.6 \pm 0.3$ & 2 \\
\hline
\end{tabular}

$\delta^{13} \mathrm{C}$ values of most meiofauna samples fell within a relatively narrow range from $-19.9 \pm 0.3$ to $-18.6 \pm 0.2 \%$ in summer and -17.9 to $-16.2 \pm 0.3 \%$ in winter. The most ${ }^{13} \mathrm{C}$-enriched meiofaunal individuals were derived from the bare flat. Harpacticoid copepods showed more regional variation in summer and nematodes did in winter. Both nematodes and harpacticoids exhibited significant seasonal shift of $\delta^{13} \mathrm{C}$ values over $2.0 \%$.

Macrofauna showed wider $\delta^{13} \mathrm{C}$ variations than meiofauna. In general, the bivalve Corbicula fluminea was most ${ }^{13} \mathrm{C}$-depleted among the macrofauna and presented stable carbon isotope ratios even lower than phytoplankton in summer. While the gastropod Assiminea violacea displayed regional variations of $2.7 \%$ in summer and $2.5 \%$ in winter, the individuals distributed in the cordgrass zone exhibited the most enriched $\delta^{13} \mathrm{C}$ values in summer $(-16.2 \pm 0.3 \%)$ but the most depleted $\delta^{13} \mathrm{C}$ values in winter $(-20.6 \pm 0.3 \%$ o) among macrofauna species, implying marked seasonal variation in this deposit feeder. In addition to significant seasonal variation in stable carbon isotopic signatures, $\delta^{13} \mathrm{C}$ values of Ilyoplax deschampsi were always lower in the cordgrass zone than in the sediment of the creek bank and bulrush zone, suggesting consistent regional variation among this ocypodid crab. As the only species of benthic feeding verte-

High abundances of Pseudodiaptomus poplesia were found in creeks of Jiuduansha salt marsh; these detritivorous copepods exhibited $\delta^{13} \mathrm{C}$ values of $-24.6 \pm$ $0.5 \%$ in summer and $-25.9 \pm 0.3 \%$ in winter, closest among all the consumers to $\mathrm{C}_{3}$ plants. Another dominant planktonic copepod in creeks was Sinocalanus sinensis, which presented $\delta^{13} \mathrm{C}$ values higher than $P$. poplesia, especially in winter $(-23.8 \pm 0.4 \%)$. Abundant Limnoithona sinensis could be found both in creeks and open waters around Jiuduansha salt marsh; the $\delta^{13} \mathrm{C}$ values of this omnivorous species were similar to $S$. sinensis. Tortanus vermiculus was the major carnivorous copepod in the Yangtze River estuary and displayed the most enriched $\delta^{13} \mathrm{C}$ values in planktonic copepod samples.

Although extreme enriched carbon isotopic signatures were found in meiofauna located in sediment of the upland creek bank during winter sampling, the brate in the present study, mudskipper Boleophthalmus pectinirostris was most ${ }^{13} \mathrm{C}$-enriched among the macrofauna in summer.

Nekton species could be divided into 2 categories by distinct stable carbon isotopic signatures and small variations within species. While goby Synechogobius ommaturus exhibited depleted $\delta^{13} \mathrm{C}$ values both in summer $(-19.8 \pm 0.3 \%$ o) and winter $(-22.0 \pm 0.3 \%$ ), mullet Mugil cephalus and shrimp Palaemon sp. had much higher $\delta^{13} \mathrm{C}$ values.

Stable nitrogen isotope ratios of consumers varied between $6.0 \pm 0.2$ and $14.2 \pm 0.2 \%$ in summer and between 6.8 and $13.6 \pm 0.3 \%$ in winter. The mean $\delta^{15} \mathrm{~N}$ value for all consumers sampled was $9.3 \%$ in summer and $8.6 \%$ in winter. Most invertebrates showed $\delta^{15} \mathrm{~N}$ values that were more depleted than $10.5 \%$, except for Tortanus vermiculus $(12.1 \pm 0.2 \%$ in summer and $12.3 \pm 0.2 \%$ in winter) and Palaemon sp. (12.6\% in 
summer), while all fish exhibited $\delta^{15} \mathrm{~N}$ values that were more enriched than $10.5 \%$.

The $\delta^{15} \mathrm{~N}$ values of Tortanus vermiculus $(12.1 \pm 0.2 \%$ in summer and $12.3 \pm 0.2 \%$ in winter) were significantly higher than those of other copepods, indicating this carnivorous copepod might occupy a higher trophic level. Besides the samples from the upland creek bank, the $\delta^{15} \mathrm{~N}$ values of meiofauna were always most enriched in bare flat samples and most depleted in samples from the bulrush zone. The stable nitrogen isotope ratios of most macrofauna were decreased in winter except for Assiminea violacea. This gastropod exhibited distinct $\delta^{15} \mathrm{~N}$ values in the cordgrass zone between summer and winter, implying there might be a food switch in this deposit feeder. The nekton Palaemon sp., Synechogobius ommaturus and Mugil cephalus were the most $\delta^{15} \mathrm{~N}$-enriched consumers among sampled animals and could be defined as predators.

\section{Trophic relationships between producers and consumers}

Dual isotope plots of $\delta^{13} \mathrm{C}$ vs. $\delta^{15} \mathrm{~N}$ provided a visual characterization of the food web structure and could be used to assess relationships among consumers and potential organic matter sources. Three trophic levels could be discriminated in the food web of Jiuduansha salt marsh both in summer (Fig. 2a) and winter (Fig. 2b). The primary level included $\mathrm{C}_{3}$ plants (cluster 1), SPM (cluster 2), phytoplankton (cluster 3), MPB (cluster 4) and $\mathrm{C}_{4}$ plant (cluster 5). The second level consisted of primary consumers, mainly herbi- and omnivorous copepods (cluster 6) in the water and meio- and macrofauna (cluster 7) inhabiting the mud substrate. The third level was composed of carnivorous consumers (cluster 8), and all of these predators were sampled in the water columns around the marsh.

During summer sampling, 2 species of herbivorous planktonic copepods, Pseudodiaptomus poplesia and Sinocalanus sinensis showed $\delta^{13} \mathrm{C}$ values that fell in the middle of $\mathrm{C}_{3}$ plants and phytoplankton, indicating they relied mostly on these 2 food sources. While the carbon isotopic signatures of $S$. sinensis did not change much in winter, the $\delta^{13} \mathrm{C}$ values of $P$. poplesia implied $\mathrm{C}_{3}$ plants played a major role in its diet. Since the carbon isotopic signatures of Limnoithona sinensis were similar to $S$. sinensis both in summer and winter, this omnivorous copepod should mainly have gained nutrients from $\mathrm{C}_{3}$ plants and phytoplankton. Although the $\delta^{15} \mathrm{~N}$ values of Tortanus vermiculus were markedly higher than other planktonic copepods samples, as the most depleted $\delta^{13} \mathrm{C}$ values among predators, it might also dependent on carbon from $\mathrm{C}_{3}$ plants and phytoplankton. Results from IsoSource demonstrated a significant role for fresh $\mathrm{C}_{3}$ plants in the diets of planktonic copepods, with a minimum contribution of $45 \%$ in summer and $66 \%$ in winter (Figs. $3 \& 4$ ). MPB might also be utilized by planktonic copepods while other producers contributed little (Figs. 3 \& 4).

Dual isotope plots illustrated that MPB was the major food source for meiofauna. While all meiofauna species had $\delta^{13} \mathrm{C}$ values close to that of MPB, their $\delta^{15} \mathrm{~N}$ values also overlapped each other, even in the ${ }^{13} \mathrm{C}$-enriched samples derived from upland creek banks in the winter. Phytoplankton might be another important carbon source for meiofauna, particularly for the individuals 


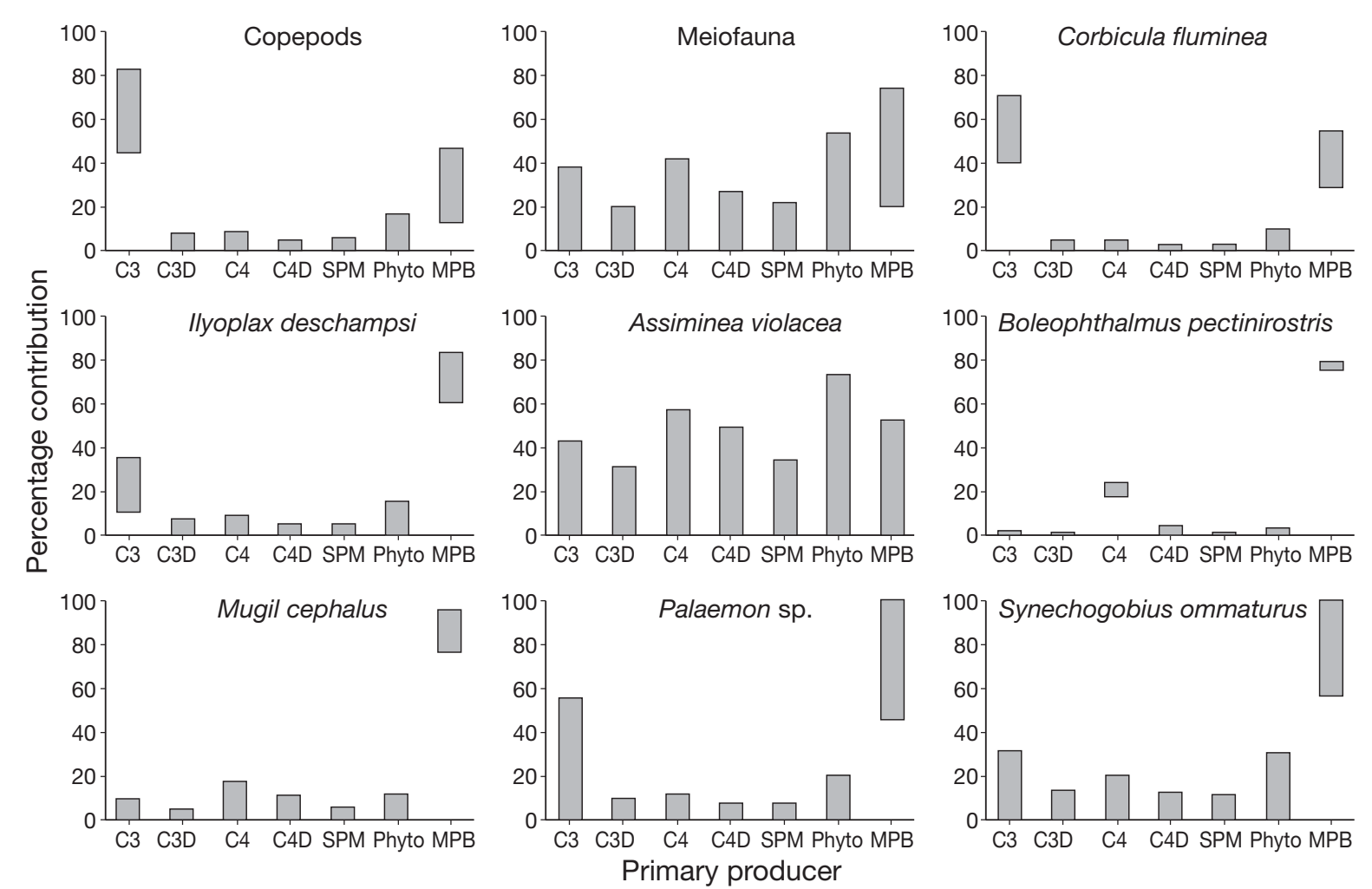

Fig. 3. Range of feasible contributions of primary producers to the diets of marsh consumers in summer, as determined by IsoSource

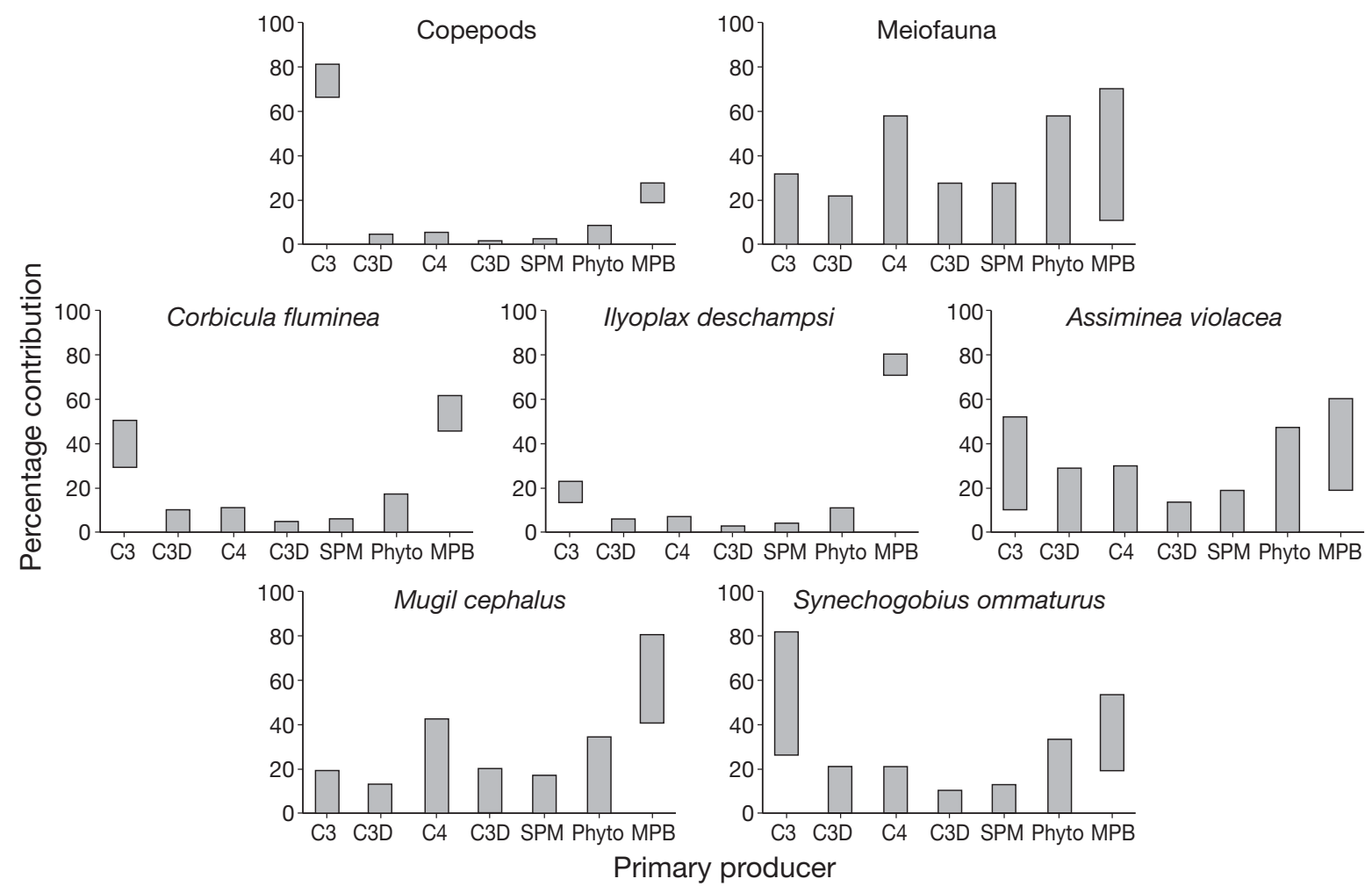

Fig. 4. Range of feasible contributions of primary producers to the diets of marsh consumers in winter, as determined by IsoSource 
residing in the bulrush zone and bare flat. IsoSource calculations showed only MPB had the minimum contribution higher than $0 \%$; MPB also had the highest maximum contribution both in summer $(74 \%)$ and winter $(70 \%)$ (Figs. $3 \& 4$ ). However, the large ranges between minimum and maximum contributions of all primary producers implied the diets of meiofauna had a lot of uncertainty (Figs. $3 \& 4$ ).

Most of the $\delta^{13} \mathrm{C}$ values of macrofauna were within or slightly higher than the range of algae (phytoplankton and MPB), indicating that algal production sustained these primary consumers. The ${ }^{13} \mathrm{C}$-depleted bivalve seemed to depend primarily on phytoplankton, but carbon derived from $\mathrm{C}_{3}$ plants might also be consumed by this filter feeder especially in summer. The isotopic signatures of gastropods sampled in the cordgrass zone fell between MPB and $\mathrm{C}_{4}$ plants in summer, implying $\mathrm{C}_{4}$ plants could be an alternative food of this deposit consumer. IsoSource results showed carbon sources derived both from fresh tissues of $\mathrm{C}_{3}$ plants and MPB were important in the diets of bivalves, while the contribution of other producers was small (Figs. 3 \& 4). MPB was the primary food source for ocypodid crab and mudskippers with minimum contributions higher than $60 \%$ (Figs. $3 \& 4$ ). The minimum and maximum contributions of producers in the diets of gastropods showed large uncertainty in summer, while MPB and fresh $\mathrm{C}_{3}$ plants might be more important in winter (Figs. 3 \& 4 ).

The enriched $\delta^{13} \mathrm{C}$ and $\delta^{15} \mathrm{~N}$ values of Mugil cephalus and Palaemon sp. indicated these predators should feed on ${ }^{13} \mathrm{C}$-enriched primary consumers, such as meiofauna. As the top consumer in the present study, the depleted carbon isotopic signatures of Synechogobius ommaturus showed more zooplanktonic food in their diet. IsoSource output indicated the significant contribution of MPB in the food base of nekton consumers except goby in winter, which relied on both $\mathrm{C}_{3}$ plants and MPB (Figs. 3 \& 4). Based on natural stable isotope ratio analyses, relative contribution of dominant producers and the major trophic transferring pathways could be summarized as in Fig. 5 .

\section{DISCUSSION}

\section{Food sources of benthic consumers}

While it is generally assumed that the benthic food webs of salt marshes in the Yangtze River estuary are detritus based (Lu 2003), the relative importance of different primary producers has not been studied previously, especially for algal production. Qualitative examination of the stable isotopic signatures of dominant producers and benthic consumers in Jiuduansha

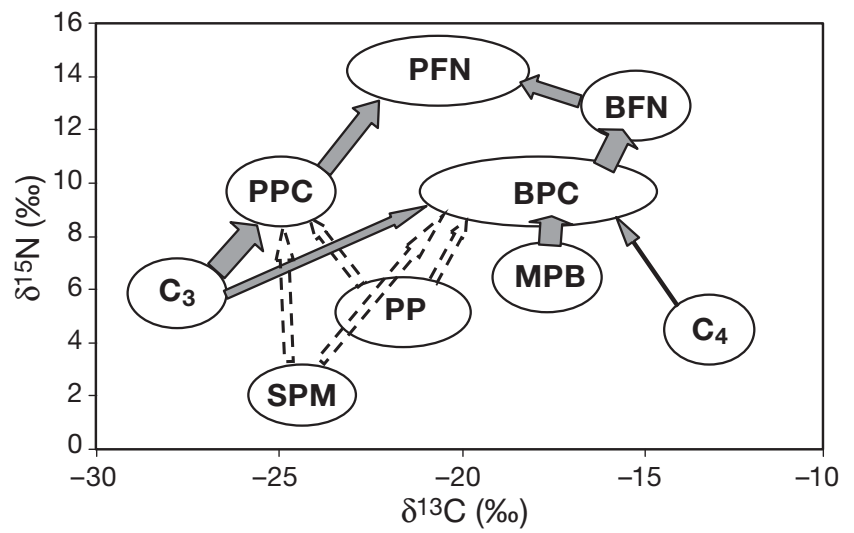

Fig. 5. Schematic view of $\delta^{13} \mathrm{C}$ and $\delta^{15} \mathrm{~N}$ values and food web in Jiuduansha salt marsh. $\mathrm{C}_{3}, \mathrm{C}_{3}$ vascular plants; SPM, suspended particulate matter; $\mathrm{PP}$, phytoplankton; $\mathrm{MPB}$, microphytobenthos; $\mathrm{C}_{4}$, Spartina; $\mathrm{PPC}$, pelagic primary consumers; $\mathrm{BPC}$, benthic primary consumers; PFN, pelagic feeding nekton; $\mathrm{BFN}$, benthic feeding nekton. Wider arrows: larger trophic contribution; dashed arrows: uncertain contribution

islands suggests the contribution from benthic and pelagic microalgae deserves more attention (Fig. 2). IsoSource estimations also demonstrate the importance of MPB, but the role of phytoplankton seems uncertain (Figs. 3 \& 4)

The high nutritional value of benthic microalgae for marsh consumers has long been supposed (Teal 1962, Pomeroy \& Wiegert 1981). MPB are mainly diatoms which have siliceous frustules rather than cellulosic cell walls of vascular plants, so that these unicellular algae can be more easily ingested by benthic consumers. High surface area to volume ratio of these cells also facilitates enzymatic digestion. More nutritious and labile than vascular plants, MPB have been regarded as a major food source of meiofauna (Miller et al. 1996). Indeed, many stable isotope studies have confirmed the tight nutritional relationship of meiofauna and MPB (Riera et al. 1996, Middleburg et al. 2000, Carman \& Fry 2002). However, the apparent $\delta^{13} \mathrm{C}$ values of meiofaunal consumers in Jiuduansha salt marsh can still be a combination from $\mathrm{C}_{3}$ plants and Spartina, but the large difference between the signatures of vascular plants and that of meiofauna increases the uncertainty of this hypothesis. Although the meiofauna in the upland creek bank exhibited very high $\delta^{13} \mathrm{C}$ values also present in Spartina during winter sampling, these enriched carbon isotopic signatures were more likely derived from the coexisting ${ }^{13} \mathrm{C}$ enriched MPB. IsoSource results showed the feasibility of other food sources utilized by meiofauna, but low minimum contribution $(0 \%)$ and large variance between minimum and maximum contributions implied the uncertainty of their role in the diets of meiofauna. 
Meiofaunal consumers always show more depleted $\delta^{13} \mathrm{C}$ values in bulrush zones than in the bare flat, implying the contribution of some ${ }^{13} \mathrm{C}$-depleted food sources besides MPB. Phytoplankton may be an alternative carbon source for they are also comprised of a high proportion of digestible and metabolizable energy and nutrients similar to MPB. Although phytoplankton is thought to be more efficiently consumed by suspension-feeding animals than deposit feeders, surface-deposited phytoplankton may constitute at least part of the diet of harpacticoids in the salt marsh (Buffan-Dubau \& Carman 2000); nematodes in the mudflat also utilize this settling labile organic carbon (Moens et al. 2005). SPM deposited into mudflat sediment may be another ${ }^{13} \mathrm{C}$-depleted carbon source for meiofauna, but low maximum feasible contribution in IsoSource calculations and relative low nutrition restrict its role in the diets of meiofauna.

The ratio of stable isotopes of nitrogen has been used widely to estimate trophic position for the $\delta^{15} \mathrm{~N}$ of a consumer and is assumed to enrich by 3 to $4 \%$ relative to its diet (DeNiro \& Epstein 1981, Peterson \& Fry 1987), but this is not the case for meiofauna in Jiuduansha salt marsh. The $\delta^{15} \mathrm{~N}$ values of meiofaunal consumers here are overlapped with, or just slightly higher than, that of MPB, the most feasible food source evaluated by IsoSource. Recent studies showed the isotopic fractionation of nitrogen by small crustaceans is not constant but depends on protein quality (Fantle et al. 1999) or nitrogen content of the diet (Adams \& Sterner 2000). High nutritional foods may result in reduced or nearly zero ${ }^{15} \mathrm{~N}$ enrichment, so low C:N ratios and high nutritional value of MPB may contribute to limited nitrogen isotope fractionations of meiofaunal consumers in the Jiuduansha salt marsh.

Macrofauna in salt marshes of the Yangtze River estuary present very different feeding behaviours, so that they may rely on different primary producers ( $\mathrm{Lu}$ 2003). Our isotopic analyses suggest that algal production constitutes the majority of the carbon in the diets of macrofauna in Jiuduansha salt marsh. However, the specific, regional and seasonal variations among $\delta^{13} \mathrm{C}$ and $\delta^{15} \mathrm{~N}$ values of macrofaunal consumers imply the relative importance of MPB and phytoplankton vary in different species, and vascular plants may also be utilized on some occasions.

Bivalve Corbicula fluminea have carbon isotopic signatures similar to that of phytoplankton, which seem consistent with their filter-feeding behaviour. However, phytoplankton is thought to comprise only a small proportion of the organic fraction of the seston in salt marshes (Langdon \& Newell 1990), and various potential food sources are available to benthic suspension feeders. Resuspended benthic microalgae are regarded as an important food source for marsh bivalves
(Riera et al. 1999, Page \& Lastra 2003); detritus of terrestrial vascular plants may also significantly contribute to the Corbicula diet (Kasai \& Nakata 2005). While feeding on a mixture of $\mathrm{C}_{3}$ plant detritus and MPB can also result in a carbon isotopic signature of consumers similar to that of phytoplankton in Jiuduansha salt marsh, these nonphytoplankton food sources may be substantial contributors of food for C. fluminea in this low-phytoplanktonic production estuary, just like IsoSource output presents.

Deposit feeders, the ocypodid crab Ilyoplax deschampsi and the gastropod Assiminea violacea, always show regional variation of carbon isotopic signatures among samples from the cordgrass zone and other habitats. The congener of I. deschampsi, I. pusilla is thought to selectively feed on benthic diatoms (Doi et al. 2005). I. deschampsi tend to feed on ${ }^{13} \mathrm{C}$-depleted food in the Spartina zone in the present study, indicating deposited phytoplankton and even detritus of $\mathrm{C}_{3}$ vascular plants and SPM may contribute to the diet of this deposit-feeding consumer. A. violacea in the cordgrass zone show a more enriched isotopic carbon signature than MPB in summer, implying the utilization of carbon from the most ${ }^{13} \mathrm{C}$-enriched Spartina. While some isotopic analyses indicate Assiminea may selectively feed on or ingest benthic microalgae (Rodelli et al. 1984, Bouillon et al. 2002), other studies define them as unselective feeders which can assimilate carbon from the detritus of vascular plants (Kurata et al. 2001, Doi et al. 2005). Our IsoSource results indicate $A$. violacea may utilize all sorts of food in Jiuduansha salt marsh, while MPB and fresh $\mathrm{C}_{3}$ plants are more important in winter. However, A. violacea exhibit more depleted $\delta^{13} \mathrm{C}$ values in the cordgrass zone than in other habitats in winter, implying detritus from $\mathrm{C}_{3}$ plants may be dominant in deposited organic matter, as most of the $\mathrm{C}_{3}$ vascular plants are dead while Spartina is still flourishing in winter.

Although some mudskippers are carnivorous, in situ observation and gut analyses reveal Boleophthalmus pectinirostris is predominantly grazing on the intertidal mudflat MPB (Yang et al. 2003, Al-Zaidan et al. 2006). Similar to the individuals that live in the mangrove marsh of Malaysia (Rodelli et al. 1984) and soft mud intertidal flats by the Arabian Gulf (Al-Zaidan et al. 2006), the stable isotopic analyses on B. pectinirostris in Jiuduansha salt marsh indicate MPB is also their main food source.

\section{Food sources of pelagic consumers}

Planktonic copepods had the most depleted carbon isotope values among all the consumers in the present study, indicating that these consumers seem to utilize a 
considerable proportion of carbon sources derived from $\mathrm{C}_{3}$ marsh plants and phytoplankton (Fig. 2), IsoSource analyses also show the tight trophic relationship between planktonic copepods and $\mathrm{C}_{3}$ plants (Figs. 3 \& 4). Although planktonic copepods exhibit significant food selectivity, and their preference for more nutritious phytoplankton has been mentioned (Bouillon et al. 2000, Müller-Solger et al. 2002), detritus of vascular plants or macrophytes can also enter the diet of planktonic copepods (Roman 1984, Hummel et al. 1988). Moreover, there may be seasonal shifts in the importance of microalgal and terrestrial production in diets of planktonic copepods (Grey et al. 2001, Kibirige et al. 2002). As SPM in the Yangtze River estuary is largely composed of $\mathrm{C}_{3}$ plant-derived organic matter carried by the Yangtze River (Zhang et al. 2002), low biomass and production of phytoplankton may restrict its importance in the diets of suspension-feeding zooplankton in this estuary (Shen et al. 1999). Skeletonema costatum is the dominant phytoplankton species in the Yangtze River estuary and also dominates the phytoplankton community in the water column around Jiuduansha salt marsh (Chen et al. 2003, Li et al. 2007). Freshwater and suspended benthic algae account for only a small proportion to the total phytoplankton biomass here (Chen et al. 2003), implying their depleted or enriched $\delta^{13} \mathrm{C}$ signatures may have minor impact on the stable carbon isotope signatures of the bulk of phytoplankton. Planktonic copepods such as Pseudodiaptomus can maintain populations in estuaries with net seaward flow by vertical migration to make use of stratified flows or lateral movement to areas of decreased flushing as in channel margins (Morgan et al. 1997, Ueda et al. 2004). These brackish copepods dominate the zooplankton community in the water column around Jiuduansha salt marsh, and only few freshwater species can be found (Chen et al. 2003), so that the stable isotope characteristics of these resident copepods can reflect feeding conditions in situ rather than the situation upstream.

Pseudodiaptomus poplesia in Jiuduansha islands show carbon isotopic signatures closest to $C_{3}$ plants among all the dominant consumers, implying that ${ }^{13} \mathrm{C}$ depleted production may be the most important food sources of these demersal copepods, just like their congener $P$. hessei, which has significant food contribution from the detritus of vascular plants (Kibirige et al. 2002). The $\delta^{13} \mathrm{C}$ values of Sinocalanus sinensis are higher than $P$. poplesia both in summer and winter, so that this pelagic copepod may rely on ${ }^{13} \mathrm{C}$-enriched phytoplankton more, but organic matter from $\mathrm{C}_{3}$ vascular plants can still constitute a considerable proportion in their diet. The pathway by which the carbon of terrestrial $\mathrm{C}_{3}$ vascular plants is incorporated into herbivorous planktonic copepods remains uncertain.
These copepods may ingest the detritus of $\mathrm{C}_{3}$ plants and its associated bacteria directly, like the utilization of seagrass detritus by Acartia (Roman 1984, Buskey et al. 1999). Another possible explanation is these 'herbivorous' copepods also feed on planktonic protozoans, which in turn have fed on bacteria nourished by the detritus of $\mathrm{C}_{3}$ plants (Stoecker \& Capuzzo 1990). As this 'carnivorous' feeding may result in significant ${ }^{15} \mathrm{~N}$ enrichment, the role of ${ }^{13} \mathrm{C}$-depleted SPM may be important in the diets of zooplankton in this highturbidity and low-chl a estuary, although depleted $\delta^{15} \mathrm{~N}$ values conceal its contribution in IsoSource evaluation. Similar to Oithona species which are thought to be predominantly omnivores (Turner 2004), Limnoithona also preys on motile mixotrophic and heterotrophic ciliates and phytoflagellates, except for diatoms (Bouley \& Kimmerer 2006). Omnivorous feeding of L. sinensis may result in their $\delta^{15} \mathrm{~N}$ values being higher than $P$. poplesia and $S$. sinensis in the present study, but they also derive carbon mainly from $\mathrm{C}_{3}$ vascular plants and phytoplankton. The $\delta^{15} \mathrm{~N}$ values of Tortanus vermiculus are significantly more enriched than other copepods, which is consistent with the predatory feeding of the genus Tortanus (Hooff \& Bollens 2004), so that they present the carbon isotopic signatures as a mixture of $\mathrm{C}_{3}$ plants and phytoplankton by ingesting herbi- and omnivorous copepods.

A former study based on gut content analysis showed no fish has a purely algal diet in the Yangtze River estuary, as their prey include benthic and pelagic invertebrates, even small fish (Luo et al. 1997). Two main food chains have been assumed, one is based on detritus and MPB $(\rightarrow$ meio- and macrofauna $\rightarrow$ small benthic fish $\rightarrow$ high trophic-level fish), and the other relies on phytoplanktonic production ( $\rightarrow$ zooplankton $\rightarrow$ small pelagic fish $\rightarrow$ high trophic-level fish). Other investigations of fishery resources around Jiuduansha islands also define fish here as secondary consumers, and they may derive carbon mainly from detritus and MPB (Chen et al. 2003, Tang et al. 2003). Our results identified the possibility that there are 2 main pathways of nutrition in the food webs of nekton in Jiuduansha salt marsh. But unlike former assumptions, one was based on MPB mainly and transferred by meioand macrofauna; the other was based on the mixture composed of detritus from terrestrial $\mathrm{C}_{3}$ plants and phytoplankton, and transferred by zooplankton (Fig. 5).

The isotopic signatures of Mugil cephalus and Palaemon sp. indicate they obtain ${ }^{13} \mathrm{C}$-enriched carbon from MPB through preferentially consuming meiofauna both in summer and winter, which is consistent with their epibenthic feeding behavior. The $\delta^{13} \mathrm{C}$ values of goby Synechogobius ommaturus exhibit marked seasonal variation, implying their selective feeding results in more ${ }^{13} \mathrm{C}$-enriched food such as abundant 
Palaemon sp. and Boleophthalmus pectinirostris during productive summer, but entirely shifts to ${ }^{13} \mathrm{C}$ depleted zooplanktonic diets in the low-yield winter.

Since salt marshes are thought to be important nursery and feeding areas, the food sources of nekton living in and around salt marshes have long been of concern. Stable isotopic analyses indicate the food web of nekton in the salt marsh may depend on algal production (Sullivan \& Moncreiff 1990) or on a mixture of various primary producers including vascular plants (Wainright et al. 2000, Weinstein \& Litvin 2000). How the carbon of these primary producers is integrated into higher trophic levels is often ignored. For example, although carbon isotopic signatures of terrestrial plants are often found in estuarine nekton, whether these nutrients are transported by zooplankton, meiofauna or macrofauna is still unknown. Our results show ${ }^{13} \mathrm{C}$-depleted carbon of vascular plants may be utilized by planktivorous nekton which feed on detritivorous or bacterivorous zooplankton, while carbon from ${ }^{13} \mathrm{C}$-enriched MPB may be transferred to benthivorous nekton by meio- and macrofauna. As estuarine nekton often exhibit great flexibility in feeding, they may tend to obtain nutrition from the most accessible carbon source regionally (Wainright et al. 2000) or seasonally (such as Synechogobius ommaturus in the present study).

\section{Impact of Spartina invasion on the food web of Jiuduansha salt marsh}

Spartina alterniflora is a dominant cordgrass native to the eastern US, which forms one of the greatest aboveground net productions in the world and yields large quantities of detritus within salt marshes and in the adjacent estuarine and coastal waters. Although many researchers report that salt marsh food webs are mainly fueled by algal producers, especially benthic microalgae (e.g. Sullivan \& Moncreiff 1990), the detritus derived from $S$. alterniflora can play an important role in the food web of salt marshes along the Atlantic coastal ecosystems of North America (e.g. Currin et al. 1995). However, the trophic contribution of $C_{3}$ plants may overcome that of Spartina when they co-occur in a same marsh (Stribling \& Cornwell 1997, Wainright et al. 2000). More than $80 \%$ of the biomass of S. alterniflora is comprised of refractory structural lignocellulose, and it is among the toughest marsh plants and does not decompose easily (Pennings et al. 1998). Stable carbon isotope analysis of microbial biomarkers also suggest the $\mathrm{C}_{3}$ plant Scirpus maritimus is a more important carbon source for bacterial growth than $\mathrm{C}_{4}$ Spartina (Boschker et al. 1999), so that production from $\mathrm{C}_{3}$ vascular plants can be utilized more easily through the bacterial pathway.
Stable isotopic analyses of dominant producers and consumers in Jiuduansha salt marsh suggest the trophic contribution of the invasive Spartina alterniflora may be limited in the local food web. Only the deposit-feeding snail Assiminea violacea shows incorporation of enriched $\delta^{13} \mathrm{C}$ carbon from S. alterniflora in summer. The small difference between the $\delta^{13} \mathrm{C}$ values of S. alterniflora and that of MPB in the upland creek bank may cause a specious interpretation of trophic importance of cordgrass in winter, but the more easily assimilated MPB is assumed to be preferred by meiofaunal consumers under high MPB yield there. Most macrofaunal consumers in the cordgrass zone exhibit more depleted $\delta^{13} \mathrm{C}$ values than in other habitats, indicating the contribution of phytoplankton and even $\mathrm{C}_{3}$ vascular plants. The invasion of $S$. alterniflora may decrease species diversity and alter the trophic group structure of the macrofauna community ( $\mathrm{hhu} \& \mathrm{Lu}$ 2003, Chen et al. 2005), which may partly be attributed to the exclusion of Spartina from the diet of most native animals. While some other studies suggest the variation on abundance and diversity of macrofauna among the cordgrass zone and other habitats are insignificant, increased proportions of gastropods among the macrofauna community imply a trophic shift in Spartina vegetation (Zhou et al. 2006).

Investigations on invasive Spartina reported alteration of faunal composition and abundance (e.g. Hedge \& Kriwoken 2000), and some predicted possible food web changes (Simenstad \& Thom 1995). But only a few studies recently focused on the trophic shift after invasion of Spartina and document the bottom-up control of the community structure of benthos (Levin et al. 2006). Although the structure of the macrofaunal community may also be regulated by habitat-flow interactions, physiological tolerance and top-down control (Neira et al. 2006), invader-mediated changes in food availability would alter trophic structure and hence community structure substantially (Levin et al. 2006). While most of the native animals seem to prefer native marsh flora to $S$. alterniflora, the rapid expansion of the invader cordgrass may be a threat as they will impact the production and distribution of native marsh flora. $S$. alterniflora has strong competitive effects on bulrush Scirpus mariqueter and results in significant decreases of $S$. mariqueter abundance in the Yangtze River estuary (Chen et al. 2004); it has also expanded to cover previously unvegetated mudflat habitat in Jiuduansha islands (unpubl. data). As the riverine sediment supply decreased dramatically after the construction of Three Gorges Dam, the progradation rate of Jiuduansha islands decreased and has shifted to degradation in recent years (Yang et al. 2005). As a drastic recession of salt marshes in the Yangtze River estuary can be expected to occur, the expansion of 
Spartina may remarkably reduce the niches where native $\mathrm{C}_{3}$ vascular plants and MPB grow, therefore probably endangering the food sources of many native animals that live in and around this estuary.

\section{CONCLUSIONS}

Based on the results of natural stable isotope analyses and IsoSource estimation, the food web of Jiuduansha salt marsh can be divided into 2 relatively independent parts. The benthic consumers primarily feed on benthic microalgae, while pelagic consumers mainly rely on carbon sources derived from autochthonous and allochthonous $\mathrm{C}_{3}$ plant-derived organic matter. Phytoplankton can be utilized by all the consumers, but low production in this high-turbidity estuary may restrict its relative importance in the diets of animals. Carbon from ${ }^{13} \mathrm{C}$-enriched MPB and ${ }^{13} \mathrm{C}$-depleted $\mathrm{C}_{3}$ plants are transported to high trophic levels by zoobenthos and zooplankton, respectively. These 2 pathways overlap at higher trophic level consumers. The contribution of Spartina alterniflora in the food web of Jiuduansha salt marsh is inconspicuous, so we predict the rapid expansion of this invading $\mathrm{C}_{4}$ plant may change the nutrient foundation of resident and migratory consumers, and hence impact the ecosystem through bottom-up processes.

Acknowledgements. The present study was funded by the Ministry of Education of PR China (No. PCSIRT0427). We are grateful to L. Levin and N. Baer for comments and linguistic checking.

\section{LITERATURE CITED}

Adams TS, Sterner RW (2000) The effect of dietary nitrogen content on trophic level ${ }^{15} \mathrm{~N}$ enrichment. Limnol Oceanogr 45:601-607

Al-Zaidan ASY, Kennedy H, Jones DA, Al-Mohanna SY (2006) Role of microbial mats in Sulaibikhat Bay (Kuwait) mudflat food webs: evidence from $\delta^{13} \mathrm{C}$ analysis. Mar Ecol Prog Ser 308:27-36

Benstead JP, March JG, Fry B, Ewel KC, Pringle CM (2006) Testing IsoSource: stable isotope analysis of a tropical fishery with diverse organic matter sources. Ecology 87: 326-333

Blanchard GF, Guarini JM, Dang C, Richard P (2004) Characterizing and quantifying photoinhibition in intertidal microphytobenthos. J Phycol 40:692-696

Boesch DF, Turner RE (1984) Dependence of fishery species on salt marshes: the role of food and refuge. Estuaries 7: 460-468

Boschker HTS, de Brouwer JFC, Cappenberg TE (1999) The contribution of macrophyto-derived organic matter to microbial biomass in salt-marsh sediments: stable carbon isotope analysis of microbial biomarkers. Limnol Oceanogr 44:309-319

Bosley KL, Wainright SC (1999) Effects of preservatives and acidification on the stable isotope ratios $\left({ }^{15} \mathrm{~N}:{ }^{14} \mathrm{~N},{ }^{13} \mathrm{C}:{ }^{12} \mathrm{C}\right)$ of two species of marine animals. Can J Fish Aquat Sci 56: 2181-2185

> Bouillon S, Chandra Mohan P, Sreenivas N, Dehairs F (2000) Sources of suspended organic matter and selective feeding by zooplankton in an estuarine mangrove ecosystem as traced by stable isotopes. Mar Ecol Prog Ser 208:79-92

Bouillon S, Koedam N, Raman AV, Dehairs F (2002) Primary producers sustaining macro-invertebrate communities in intertidal mangrove forests. Oecologia 130:441-448

> Bouley P, Kimmerer WJ (2006) Ecology of a highly abundant, introduced cyclopoid copepod in a temperate estuary. Mar Ecol Prog Ser 324:219-228

Buffan-Dubau E, Carman KR (2000) Diel feeding behavior of meiofauna and their relationships with microalgal resources. Limnol Oceanogr 45:381-395

Bunn SE, Loneragan NR, Kempster MA (1995) Effects of acid washing on stable isotope ratios of $\mathrm{C}$ and $\mathrm{N}$ in penaeid shrimp and seagrass: implications for food-web studies using multiple stable isotopes. Limnol Oceanogr 40: $622-625$

Buskey EJ, Dunton KH, Parker PL (1999) Variations in stable carbon isotope ratio of the copepod Acartia tonsa during the onset of the Texas brown tide. Estuaries 22:995-1003

Carman KR, Fry B (2002) Small-sample methods for $\delta^{13} \mathrm{C}$ and $\delta^{15} \mathrm{~N}$ analysis of the diets of marsh meiofaunal species using natural-abundance and tracer-addition isotope techniques. Mar Ecol Prog Ser 240:85-92

Chen JK, Ma ZJ, Li B, Yuan JF, Zhang Z (2003) Comprehensive surveys on Shanghai Jiuduansha Wetland nature reserve, the Yangtze River estuary. Science Press, Beijing

> Chen ZY, Li B, Zhong Y, Chen JK (2004) Local competitive effects of introduced Spartina alterniflora and Scirpus mariqueter at Dongtan of Chongming Island, the Yangtze River estuary and their potential ecological consequences. Hydrobiologia 528:99-106

Chen ZY, Fu CC, Wang HY, Li B, Wu JH, Chen JK (2005) Effects of Spartina alterniflora invasions on the benthic macro-invertebrates community at Dongtan of Chongming salt marsh, the Yangtze River estuary. Wetland Sci 3:1-7 (in Chinese with English abstract)

Currin CA, Newell SY, Paerl HW (1995) The role of standing dead Spartina alterniflora and benthic microalgae in saltmarsh food webs: considerations based on multiple stable isotope analysis. Mar Ecol Prog Ser 121:99-116

> DeNiro MJ, Epstein S (1978) Influence of diet on the distribution of carbon isotopes in animals. Geochim Cosmochim Acta 42:495-506

DeNiro MJ, Epstein S (1981) Influence of diet on the distribution of nitrogen isotopes in animals. Geochim Cosmochim Acta 45:341-353

Doi H, Matsumasa M, Toya T, Satoh N, Mizota C, Maki Y, Kikuchi E (2005) Spatial shifts in food sources for macrozoobenthos in an estuarine ecosystem: carbon and nitrogen stable isotope analyses. Estuar Coast Shelf Sci 64: 316-322

> Fantle MS, Dittel AI, Schwalm SM, Epifanio CE, Fogel ML (1999) A food web analysis of the juvenile blue crab, Callinectes sapidus, using stable isotopes in whole animals and individual amino acids. Oecologia 120:416-426

> France RL (1995) Carbon-13 enrichment in benthic compared to planktonic algae: food web implications. Mar Ecol Prog Ser 124:307-312

Gee JM (1989) An ecological and economic review of meiofauna as food for fish. Zool J Linn Soc 96:243-261

Grey J, Jones RI, Sleep D (2001) Seasonal changes in the importance of the source of organic matter to the diet of 
zooplankton in Loch Ness, as indicated by stable isotope analysis. Limnol Oceanogr 46:505-513

Hedge P, Kriwoken LK (2000) Evidence for the effects of Spartina anglica invasion on benthic macrofauna in Little Swanport estuary, Tasmania. Austral Ecol 25:150-159

Herman PMJ, Middelburg JJ, Widdows J, Lucas CH, Heip CHR (2000) Stable isotopes as trophic tracers: combining field sampling and manipulative labeling of food resources for macrobenthos. Mar Ecol Prog Ser 204:79-92

Hooff RC, Bollens SM (2004) Functional response and potential predatory impact of Tortanus dextrilobatus, a carnivorous copepod recently introduced to the San Francisco Estuary. Mar Ecol Prog Ser 277:167-179

Huang H, Zhang LQ (2007) A study of the population dynamics of Spartina alterniflora at Jiuduansha shoals, Shanghai, China. Ecol Eng 29:164-172

Hummel H, Moerland G, Bakker C (1988) The concomitant existence of a typical coastal and a detritus food chain in the Westerschelde Estuary. Hydrobiol Bull 22:35-41

Kasai A, Nakata A (2005) Utilization of terrestrial organic matter by the bivalve Corbicula japonica estimated from stable isotope analysis. Fish Sci 71:151-158

Kibirige I, Perissinotto R, Nozais C (2002) Alternative food sources of zooplankton in a temporarily-open estuary: evidence from $\delta^{13} \mathrm{C}$ and $\delta^{15} \mathrm{~N}$. J Plankton Res 24:1089-1095

Kneib RT (1997) The role of tidal marshes in the ecology of estuarine nekton. Oceanogr Mar Biol Annu Rev 35: $163-220$

Kurata K, Minami H, Kikuchi E (2001) Stable isotope analysis of food sources for salt marsh snails. Mar Ecol Prog Ser 223:167-177

Langdon CJ, Newell RIE (1990) Utilization of detritus and bacteria as food sources by two bivalve suspension-feeders, the oyster Crassostrea virginica and the mussel Geukensia demissa. Mar Ecol Prog Ser 58:299-310

Levin LA, Neira C, Grosholz ED (2006) Invasive cordgrass modifies wetland trophic function. Ecology 87:419-432

Lewis VP, Peters DS (1984) Menhaden-a single step from vascular plant to fishery harvest. J Exp Mar Biol Ecol 84: 95-100

Li HP, Zhang LQ, Wang DH (2006) A study on the distribution of an exotic plant Spartina alterniflora in Shanghai. Biodiversity Sci 14:114-120 (in Chinese with English Abstract)

Li Y, Li DJ, Tang JL, Wang YM, Liu ZG, Ding PX, He SQ (2007) Phytoplankton distribution and variation in the Yangtze River estuary and its adjacent sea. Environ Sci 28: 719-729 (in Chinese with English abstract)

Lu JJ (1997) The shorebirds in the Yangtze River estuary and the migratory route of the Asia/Pacific migrating waders. In: China Aves Soc (ed) The Int Proseminar Symp Wetland Waders Conserv. Chinese Forestry Publishing House, Beijing, p 19-25

Lu JJ (2003) Estuarine ecology. Ocean Press, Beijing (in Chinese)

Luo BZ, Wei S, Dou SZ (1997) Study on food web and trophic structure of fish in the Changjiang River estuary. Stud Mar Sin 38:143-153 (in Chinese with English abstract)

Ma ZJ, Gan XJ, Choi CY, Jing K, Tang SM, Li B, Chen JK (2007) Wintering bird communities in newly-formed wetland in the Yangtze River estuary. Ecol Res 22:115-124

McClintock JB, Klinger TS, Marion K, Hsueh P (1991) Digestive carbohydrases of the blue crab Callinectes sapidus (Rathbun): implications in utilization of plant-derived detritus as a trophic resource. J Exp Mar Biol Ecol 148:233-239

McCutchan JJH, Lewis JWM, Kendall C, McGrath CC (2003) Variation in trophic shift for stable isotope ratios of carbon, nitrogen, and sulfur. Oikos 102:378-390
Michener RH, Schell DM (1994) Stable isotope ratios as tracers in marine aquatic food webs. In: Lajtha $\mathrm{K}$, Michener $\mathrm{RH}$ (eds) Stable isotopes in ecology and environmental science. Blackwell, Oxford, p 138-157

Middleburg JJ, Barranguet C, Boschkler HTS, Herman PMJ, Moens T, Heip CHR (2000) The fate of intertidal microphytobenthos carbon: an in situ ${ }^{13} \mathrm{C}$-labeling study. Limnol Oceanogr 45:1224-1234

> Miller DC, Geider RJ, MacIntyre HL (1996) Microphytobenthos: the ecological role of the 'secret garden' of unvegetated, shallow-water marine habitats. II. Role in sediment stability and shallow-water food webs. Estuaries 19:202-212

> Moens T, Bouillon S, Gallucci F (2005) Dual stable isotope abundances unravel trophic position of estuarine nematodes. J Mar Biol Assoc UK 85:1401-1407

> Morgan CA, Cordell JR, Simenstad CA (1997) Sink or swim? Copepod population maintenance in the Columbia River estuarine trubidity-maxima region. Mar Biol 129:309-317

Müller-Solger AB, Jassby AD, Müller-Navarra DC (2002) Nutritional quality of food resources for zooplankton (Daphnia) in a tidal freshwater system (Sacramento-San Joaquin River Delta). Limnol Oceanogr 47:1468-1476

Neira C, Grosholz ED, Levin LA, Blake R (2006) Mechanisms generating modification of benthos following tidal flat invasion by a Spartina hybrid. Ecol Appl 16:1391-1404

Odum EP (1961) The role of tidal marshes in estuarine production. Conservationist 15:12-15

Odum EP, de la Cruz AA (1967) Particulate organic detritus in a Georgia salt marsh-estuarine ecosystem. In: Lauff GH (ed) Estuaries. AAAS No 83, Washington, DC, p 383-388

> Page HM, Lastra M (2003) Diet of intertidal bivalves in the Ria de Arosa (NW Spain): evidence from stable C and N isotope analysis. Mar Biol 143:519-532

Pennings SC, Carefoot TH, Siska EL, Chase ME, Page TA (1998) Feeding preferences of a generalist salt-marsh crab: relative importance of multiple plant traits. Ecology 79:1968-1979

> Peterson BJ, Fry B (1987) Stable isotopes in ecosystem studies. Annu Rev Ecol Syst 18:293-320

> Peterson BJ, Howarth RW, Garritt RH (1985) Multiple stable isotopes used to trace the flow of organic matter in estuarine food webs. Science 227:1361-1363

Phillips DL, Gregg JW (2003) Source partitioning using stable isotopes: coping with too many sources. Oecologia 136: 261-269

> Pinckney J, Zingmark RG (1993) Biomass and production of benthic microalgal communities in estuarine habitats. Estuaries 16:887-897

Pomeroy LR, Wiegert RG (1981) The ecology of salt marsh. Springer, New York

Riera P, Richard P, Gremare A, Blanchard G (1996) Food source of intertidal nematodes in the Bay of MarennesOleron (France), as determined by dual stable isotope analysis. Mar Ecol Prog Ser 142:303-309

Riera P, Stal LJ, Nieuwenhuize J, Richard P, Blanchard G, Gentil F (1999) Determination of food sources for benthic invertebrates in a salt marsh (Aiguillong Bay, France) by carbon and nitrogen stable isotopes: importance of locally produced sources. Mar Ecol Prog Ser 187:301-307

Rodelli MR, Gearing JN, Gearing PJ, Marshall N, Sasekumar A (1984) Stable isotope ratio as a tracer of mangrove carbon in Malaysian ecosystems. Oecologia 61:326-333

Roman MR (1984) Utilization of detritus by the copepod, Acartia tonsa. Limnol Oceanogr 29:949-959

Shen XQ, Jiang M, Yuan Q (1999) Study on distribution of chlorophyll a in the Changjiang estuary. J Fish Sci China 6:1-5 (in Chinese with English abstract) 
Silliman BR, Zieman JC (2001) Top-down control of Spartina alterniflora production by periwinkle grazing in a Virginia salt marsh. Ecology 82:2830-2845

Simenstad CA, Thom RM (1995) Spartina alterniflora (smooth cordgrass) as an invasive halophyte in Pacific Northwest Estuaries. Hortus Northwest 6:9-12; 38-40

Smith BN, Epstein S (1971) Two categories of ${ }^{13} \mathrm{C} /{ }^{12} \mathrm{C}$ ratios for higher plants. Plant Physiol 47:380-384

Stoecker DK, Capuzzo JM (1990) Predation on protozoa: its importance to zooplankton. J Plankton Res 12:891-908

Stribling JM, Cornwell JC (1997) Identification of important primary producers in a Chesapeake Bay tidal creek system using stable isotopes of carbon and sulfur. Estuaries 20:77-85

Sullivan MJ, Moncreiff CA (1990) Edaphic algae are an important component of salt marsh food-webs: evidence from multiple stable isotope analyses. Mar Ecol Prog Ser 62:149-159

Tang WQ, Zhu TJ, Chen JK, Han HF, Sun Y (2003) Resources and conservation valuation of fishes of Jiuduansha wetland in Changjiang River estuary. J Shanghai Fish Univ 12:193-200 (in Chinese with English abstract)

Teal JM (1962) Energy flow in a salt marsh ecosystem of Georgia. Ecology 43:614-624

Teal JM, Howes BL (2000) Salt marsh values: retrospection from the end of the century. In: Weinstein MP, Kreeger DA (eds) Concepts and controversies in tidal marsh ecology. Kluwer Academic Publishers, Dordrecht, p 9-19

Turner JT (2004) The importance of small planktonic copepods and their roles in pelagic marine food webs. Zool Stud 43:255-266

Ueda H, Terao A, Tanaka M, Hibino M, Islam MS (2004) How can river-estuarine planktonic copepods survive river floods? Ecol Res 19:625-632

Vander Zanden MJ, Rasmussen JB (2001) Variation in $\delta^{15} \mathrm{~N}$

Editorial responsibility: Robert Feller,

Columbia, South Carolina, USA and $\delta^{13} \mathrm{C}$ trophic fractionation: implications for aquatic food web studies. Limnol Oceanogr 46:2061-2066

Wainright SC, Weinstein MP, Able KW, Currin CA (2000) Relative importance of benthic microalgae, phytoplankton and the detritus of smooth cordgrass Spartina alterniflora and the common reed Phragmites australis to brackishmarsh food webs. Mar Ecol Prog Ser 200:77-91

Weinstein MP, Litvin SY (2000) The role of tidal salt marsh as an energy source for marine transient and resident finfishes: a stable isotope approach. Trans Am Fish Soc 129: $797-810$

Yang KY, Lee SY, Williams GA (2003) Selective feeding by the mudskipper (Boleophthalmus pectinirostris) on the microalgal assemblage of a tropical mudflat. Mar Biol 143: $245-256$

Yang SL, Zhang J, Zhu J, Smith JP, Dai SB, Gao A, Li P (2005) Impact of dams on Yangtze River sediment supply to the sea and delta intertidal wetland response. J Geophys Res 110:F03006, doi:10.1029/2004JF000271

Zhang J, Cooper LW, Wu Y, Hong GH and others (2002) Elemental and isotopic composition of carbon and nitrogen of organic matter in plant and soils in the river bank and suspended particulate matter of the Changjiang (Yangtze River). In: Hong GH, Zhang J, Chung CS (eds) Impact of interface exchange on the biogeochemical process of the Yellow and East China Seas. Bumshin Press, Seoul, p 189-232

Zhou X, Wang TH, Ge ZM, Shi WY, Zhou LC (2006) Impact of Spartina alterniflora invasion on the macrobethos community of Jiuduansha's intertidal mudflat in the Yangtze River estuary. Biodivers Sci 14:165-171 (in Chinese with English abstract)

Zhu XJ, Lu JJ (2003) Functional groups of zoobenthos in the intertidal zone of Jiuduansha, the Yangtze River estuary. Zool Res 24:355-361 (in Chinese with English abstract)

Submitted: September 21, 2007; Accepted: May 5, 2008

Proofs received from author(s): August 30, 2008 